\title{
ARTYKULY
}

Klio. Czasopismo poświęcone dziejom Polski i powszechnym PL ISSN 1643-8191, t. 30 (3)/2014, s. 101-111

(c) $($ ) $\Theta$

http://dx.doi.org/10.12775/KLIO.2014.047

HENRYK KOWALSKI

(Lublin)

\section{Poczatki kultu wodzów i władzy charyzmatycznej w Rzymie w okresie późnej republiki}

W

1984 roku ukazał się w „Balcanica Posnaniensia” artykuł Marii Jaczynowskiej pt. Kult wodzów rzymskich w okresie republiki (III-I w. p.n.e.), a rok później w „Athenaeum” rozszerzona wersja pt. La genesi repubblicana del culto imperiale. Da Scipione l'Africano a Giulio Cesare ${ }^{1}$. Autorka przedstawiła w nich analizę początku kultu wodzów rzymskich, łącząc to zjawisko z wpływami hellenistycznymi na rozwój rzymskiej instytucji triumfu i ideologii imperatora.

Pojawienie się w III wieku p.n.e. w Rzymie elementów kultu wodzów było konsekwencją włączenia do tradycji rzymskiej idei funkcjonujących w państwach hellenistycznych, z którymi rzymscy wodzowie zetknęli się

${ }^{1}$ M. Jaczynowska, Kult wodzów rzymskich w okresie republiki (III-I w. p.n.e.), „Balcanica Posnaniensia”, 1984, t. 3, s. 157-165; eadem, La Genesi repubblicana del culto imperiale. Da Scipione l'Africano a Giulio Cesare, „Athenaeum” 1985, t. 73, s. 285-295 (= M. Jaczynowska, Studia z dziejów antycznego Rzymu, Toruń 2003, s. 56-88). 
podczas zwycięskich kampanii w Grecji i na Wschodzie². Należał do nich obyczaj oddawania czci wybitnym jednostkom: władcom, wodzom lub ludziom w inny sposób zasłużonym dla wspólnoty. Charakterystycznym elementem tego zjawiska było nadawanie przydomków bądź boskich (theos), bądź podkreślających zasługi dla danego miasta i jego społeczności (soter lub eurgetes $)^{3}$, oraz czynienie różnego rodzaju honorów podobnych do tych, które mieli bogowie. Jedną z form kultu były święta i igrzyska ${ }^{4}$.

Pierwszym, który dostąpił tego typu zaszczytu, był przypuszczalnie wódz spartański Lizander. Jak podaje Plutarch, powołując się na historyka Durisa z Samos, mieszkańcy tej wyspy wznieśli ku czci Lizandra ołtarze i składali mu ofiary oraz zapewne od 404 roku p.n.e. ustanowili igrzyska pod nazwą Lysandreia, które zastąpiły Heraia poświęcone Herze5. Od czasów Aleksandra Wielkiego igrzyska były podstawową ceremonią w kulcie władców. Tytułem przykładu można wspomnieć: Aleksandreia, organizowane przez mieszkańców Tazos, igrzyska ku czci Demetriosa Poliorketesa w Atenach (Dionysiaka i Demetreia), czy Ptolemaia w Egipcie ustanowione przez Ptolemajosa II ku czci jego zmarłego ojca ${ }^{6}$.

W oczach Greków militarne sukcesy rzymskich wodzów były pochodną boskiego wsparcia i zasługiwały na specjalne zaszczyty, ponieważ świadczyły o ich charyzmie. Na gruncie polskim pojęcie to w odniesieniu do rzymskich wodzów wprowadził Lesław Morawiecki w pracy opublikowanej w 1989 roku$^{7}$. Według klasycznej definicji M. Webera, człowiek obdarzony charyzmą dysponował nadzwyczajną mocą lub szczególnymi umiejętno-

2 C. J. Classen, Gottmenschentum in der römischen Republik, [w:] idem, Die Welt der Römer. Studien zu ihrer Literatur, Geschichte und Religion, Berlin-New York 1993, s. 12-38 (s. 15 i n.).

${ }^{3}$ H. Kasper, Griechische Soter - Vorstellungen und ibre Übernahme in das politische Leben Roms, München 1961.

${ }^{4}$ F. Taeger, Charisma. Studien zur Geschichte des antiken Herrscherkultes, t. I, Stuttgart 1957, s. 234 i n.

5 Plutarch, Lysander 18.

${ }^{6}$ M. Winiarczyk, Początki kultu wodzów i wtadców w świecie greckim (Do ok. 270 r. p.n.e.), „Meander” 1998, t. 53, z. 2, s. 135-152.

${ }^{7}$ L. Morawiecki, Wtadza charyzmatyczna w Rzymie u schytku Republiki 44-27 r. p.n.e., Rzeszów 1989. 
ściami, które objawiają się między innymi w czynach heroicznych ${ }^{8}$. Weber wyróżniał trzy typy władzy (panowania) idealnej: legalną, tradycyjną i właśnie charyzmatyczną, czyli ogólnie rzecz biorąc opartą na sile osobowości ${ }^{9}$.

O władzy charyzmatycznej rzymskich wodzów świadczyły virtutes: Fides, Iustitia, Honos, Gloria, Dignitas, Pietas, Libertas oraz Virtus, poza innymi znaczeniami, cnota oznaczająca męstwo w aspekcie militarnym. Od IV wieku p.n.e. funkcjonowały jako zestaw cnót obywatelskich ${ }^{10}$. Za pomocą tych pojęć konstruowano obraz idealnego wodza i w tym kontekście stanowiły jego cechy osobiste, ale niektóre z nich egzystowały również niezależnie, jako bóstwa.

Największy rozkwit kultów różnych virtutes przypada na III-II wiek p.n.e., kiedy to powstała większość świątyń im poświęconych (m.in. Concordia, Salus, Victoria, Ops, Spes, Fides, Libertas, Mens, Pietas). Rozwój tych kultów łączy się z początkiem imperializmu rzymskiego, a także z przejmowaniem niektórych wzorców greckich. Virtutes, podobnie jak inne bóstwa, miały własne świątynie oraz formy kultu: obrzędy, ofiary, święta itd. ${ }^{11}$.

Ich znaczenie wzrosło w okresie późnej republiki, kiedy to politycy zaczęli się odwoływać się do wymienionych pojęć, nadając im nowe znaczenie i znajdując dla nich nowe zastosowania. Dla wybitnych wodzów tej

${ }^{8}$ M. Weber, Szkice z socjologii religii, Warszawa 1984, s. 134. Por.: T. Mojsik, Charisma i charis (Charis/Charites) w świecie antycznym, [w:] Charyzma: jej funkcja wżyciu religijnym, politycznym i spotecznym, red. J. Sieradzan, Białystok 2008, s. 13-23.

${ }_{9}^{9}$ Omówienie znaczenia pojęcia charyzmy w myśli M. Webera: S. N. Eisenstadt, Introduction, [w:] M. Weber, On Charisma and Institution Building. Selected Papers, red. S. N. Eisenstadt, Chicago-London 1968, s. 9-56. T. Hölscher w wydanej ostatnio pracy zaproponował w odniesieniu do rzymskiego cesarza jeszcze jedną formę: władzę ideologiczną. Byłaby to władza rozumiana ,jako realizacja mniej lub bardziej ustalonych kanonów ideologicznych”. Zob.: T. Hölscher, Różni aktorzy - te same role. Panowanie „ideologiczne" cesarza w sztuce rzymskiej, przeł. L. Olszewski, Poznań 2014, s. 27 i n.

${ }^{10}$ M. McDonnell, Roman Manliness. "Virtus" and the Roman Republic, Cambridge 2006, 489-533. Por.: C. J. Classen, Aretai und Virtutes: Untersuchungen zu den Wertvorstellungen der Griechen und Römer, Berlin-New York 2010, s. 193 i n.

${ }^{11} \mathrm{~J}$. R. Fears, The Cult of Virtues and Roman Imperial Ideology, ANRW, II, 17,2 (Berlin 1981), s. 827-948 (zwł. 833 nn.). Por.: A. Ziolkowski, The Temples of MidRepublican Rome and Their Historical and Topographical Context, Roma 1992; E. M. Orlin, Temples, Religion and Politics in the Roman Republic, Boston-Leiden 2002, s. 199-202 (Appendix one). 
epoki, przygotowujących grunt dla swojej władzy, virtutes rozumiane, jako osobiste cnoty, jak i personifikowane obiekty kultu, odgrywały ważną rolę w uzasadnieniu ich pretensji do nadzwyczajnej władzy ${ }^{12}$. Virtutes traktowane jako osobiste przymioty, a jednocześnie jako cnoty o boskim charakterze, wskazywały na nadzwyczajne umiejętności i kompetencje wodza oraz świadczyły o przychylności bóstw dla jego władzy. Obok talentów militarnych stanowiły one podstawę dla władzy charyzmatycznej, a w konsekwencji utrwalały wpływy polityczne ${ }^{13}$.

W rozwoju kultu wodzów rzymskich i kreowania ich władzy charyzmatycznej w okresie późnej republiki w Rzymie można wyróżnić trzy etapy. Pierwszy przypada na okres II wojny punickiej, a szczególną rolę w tym procesie odegrali M. Klaudiusz Marcellus i P. Korneliusz Scypion Afrykański Starszy. Drugi etap to rządy Sulli, a zwieńczeniem procesu kształtowania się władzy charyzmatycznej republikańskich wodzów jest dominacja Juliusza Cezara na rzymskiej scenie politycznej. Oktawian August, doprowadzając do deifikacji swego przybranego ojca, nadał zjawisku władzy charyzmatycznej nowy wymiar.

M. Jaczynowska za prekursora polityki zmierzającej do wywyższenia własnej osoby uznała Scypiona Afrykańskiego, który sam uważał się za wybrańca Jowisza, mającego przywilej bezpośrednich kontaktów z bóstwami, Jowiszem i Posejdonem. Kierując się opinią Liwiusza, można przyjąć, że współcześni Afrykańczyka widzieli w nim wybrańca bogów i tym tłumaczyli jego nadzwyczajne dokonania ${ }^{14}$. Przyznano mu honorowe zaszczyty, jak posąg w stroju triumfatora w świątyni Jowisza na Kapitolu, o czym wspomina Appian, a po śmierci Scypiona, poeta Enniusz zaliczył go w poczet bogów ${ }^{15}$. Według Jaczynowskiej był to początek genezy kultu cesarskiego ${ }^{16}$. Należy jednak stwierdzić, że już nieco wcześniej pojawił się wódz, który

12 J. R. Fears, op.cit., s. 875 i n.

13 C. J. Classen, op.cit., s. $195 \mathrm{i} \mathrm{n.}$

${ }^{14}$ Liv., 26, 19, 4. Por.: M. Jaczynowka, Studia z dziejów..., s. 71 i n.

15 Appian, Hisp., 23; R. Seguin, La religion de Scipion l'Africain, „Latomus” 1974, t. 33, s. 3-21.

${ }^{16}$ M. Jaczynowska, Les origines républicaines du culte imperial, „Acta Classica Universitatis Scientiarum Debrecenensis” 1986, t. 22, s. 53-61. 
w działalności publicznej wykorzystywał autokreację, niezbędny element władzy charyzmatycznej.

Pierwszym wodzem rzymskim, któremu przyznano „boskie” zaszczyty był M. Klaudiusz Marcellus, zdobywca Syrakuz. M. McDonnell uznał go za prekursora idei „kultu wodzów”, wykorzystującego wzory hellenistyczne i propagandę virtutes w kreowaniu swego politycznego wizerun$\mathrm{ku}^{17}$. Początkiem jego sukcesów militarnych było zwycięstwo nad Gallami pod Clastidium w 222 roku p.n.e. ${ }^{18}$, kiedy to otrzymał od senatu prawo odbycia triumfu, podczas którego złożył w świątyni Jowisza na Kapitolu spolia opima ${ }^{19}$. Jednocześnie obiecał zbudować świątynię ku czci Virtus ${ }^{20}$.

W 212 roku p.n.e. Marcellus dowodził wojskami rzymskimi na Sycylii i wsławił się zdobyciem Syrakuz. Według relacji Liwiusza i Plutarcha Marcellus rozkazał zabrać z Sycylii część posąów bóstw i przewiózł je do Rzymu, za co został potem oskarżony przez Sycylijczyków. Z relacji obu autorów wynika, że Marcellus został uniewinniony dzięki błyskotliwej mowie, którą wygłosił w senacie, a Sycylijczycy prosili go o wybaczenie ${ }^{21}$. W uznaniu dla zasług został patronem Sycylii i przyznano mu przydomek Soter, oraz ufundowano jego liczne konne posagi. Ku czci Marcellusa ustanowiono święta o nazwie Marcellia, podczas których składano ofiary i urządzano igrzyska ${ }^{22}$. Przetrwały one do I wieku p.n.e., kiedy to zniósł je Werres, wprowadzając w zamian święta ku własnej czci (Verria). Cyceron honory przyznane Marcellusowi porównał do oznak kultu należnego bogom: Et enim minime conveniebat ei deorum honores haberi qui simulacra deorum abstulisset ${ }^{23}$. Powiązania religijne dotyczą także virtutes. Marcellus, jak

${ }^{17}$ McDonnell, op.cit., s. 206 i n. (rozdział VII: Divine virtus - M. Claudius Marcellus and Roman Politics).

18 Polybius, II, 35, 5; Plutarch, Marcellus, 6.

19 Plutarch, Marcellus, 8.

${ }^{20}$ L. Pietilä-Castrén, Magnificentia publica. The victory Monuments of the Roman Generals in the Era of the Punic wars, Helsinki 1987, s. 56 i n.; M. Aberson, Temples votifset butin de guerre dans la Rome republicaine, Rome 1994, s. 120 i n.;

${ }^{21}$ Livius, 26, 30-32; Plutarch, Marcellus, 23. Por.: J. B. Rives, Marcellus and the Syracusans, „Classical Philology” 1993, t. 88.1, s. 32-35.

22 Pseudo-Asconius, In. Q. Caecilium divinatio, s.187; 190 (Stangl); In Verrem, s. 209; 227; 258 (Stangl). Por.: Cicero, In Verrem, II, 4, 90-91; 115-131.

${ }^{23}$ Cicero, In Verrem, II, 4, 151. 
podaje Liwiusz, przy okazji odnowienia w 208 roku p.n.e. świątyni ku czci Honos (ufundowanej w 233 roku przez Kw. Fabiusza Werrukosusa) chciał ją poświęcić Honos i Virtus. Senat jednak nie godził się na jedną świątynię ku czci obu bóstw. Marcellus rozwiązał ten problem, zlecając dobudowanie w świątyni drugiej celli ${ }^{24}$. Świątynię Honos et Virtus dedykował ostatecznie syn Marcellusa, M. Marcellus w 205 roku p.n.e., już po śmierci ojca ${ }^{25}$.

Polityka Marcellusa i Scypiona oparta na kreowaniu własnego wizerunku, jako wybrańca bogów i budowaniu władzy charyzmatycznej z wykorzystaniem hellenistycznych wzorów, czemu sprzyjały zaszczyty przyznawane przez miasta greckie, znalazła kontynuatorów wśród wodzów rzymskich, prowadzących kampanie w Grecji w II i I wieku p.n.e. Igrzysk ku swojej czci doczekali się T. Kwinkcjusz Flamininus, L. Memmiusz oraz M. Lukullus ${ }^{26}$.

Jednym z prekursorów nowego wykorzystania religii i virtutes wpropagandzie politycznej był Lucjusz Korneliusz Sulla ${ }^{27}$. Prowadził on własną politykę religijną polegającą na odwoływaniu się do konkretnych bóstw opiekuńczych, których wskazówki miały mu zapewniać sukcesy militarne ${ }^{28}$. We współczesnej historiografii już od lat dwudziestych i trzydziestych XX wieku popularna jest hipoteza o prowadzeniu przez Sullę celowej propagandy religijnej, której ukoronowaniem miało być przygotowanie apoteozy po śmierci. Jednym z pierwszych badaczy, który zwrócił uwagę na ten problem, był polski uczony Mieczysław Stanisław Popławski, który w 1927 roku opublikował w czasopiśmie „Eos” artykuł pod tytułem L'apothéose de Sylla et Auguste ${ }^{29}$. Autor podkreślił zwłaszcza eksponowanie przez Sullę związków

${ }^{24}$ Livius, 27, 25, 7-9 ; Plutarch, Marcellus, 281; Valerius Maximus, 1,1,8.

${ }^{25}$ Livius, 29, 11, 13. Por.: M. Bieber, Honos and Virtus, "American Journal of Archeology" 1945, 49/1, s. 25-34; M. Aberson, op.cit., s. 120 i n.; A. Ziolkowski, op.cit., s. 58-60.

${ }^{26}$ R. Pfeilschifter, Titus Quinctius Flamininus: Untersuchungen zur römischen Griechenlandpolitik, Göttingen 2005; Szerzej o wodzach rzymskich jako patronach miast greckich: C. Eilers, Roman patrons of Greek Cities, Oxford 2002.

${ }^{27}$ M. Jaczynowska, La Genesis..., s. 291 i n.

28 A. Alföldi, Redeunt Saturnia Regna, V: Zum Gottesgnadentum des Sulla, „Chiron” 1976, 6, s. 143-158; A. Keaveney, Sulla and the Gods, [w:] Studies in Latin Literature and Roman History, ed. C. Deroux, vol. III, Brussels 1983, s. 44-79.

${ }^{29}$ M. S. Popławski, L'apothéose de Sylla et Auguste, „Eos” 1927, t. 30, s. 272-338. 
z boginią Fortuną i wybór felicitas jako szczególnie propagowanej wartości. Symboliczne było przyjęcie przez niego przydomka Felix oraz nadanie bliźniętom, które urodziła mu żona Metella, imion Fausta i Faustus. Innym elementem propagandy religijnej Sulli były odniesienia do bogini Venus, a nadzwyczajne relacje z tym bóstwem miał podkreślać przyjęty przez Sullę przydomek Epaphroditos oraz świątynia wystawiona tej bogini jako Venus Victrix. Patronką Sulli stała się też bogini Wiktoria, której poświęcił igrzyska ludi Victoriae Sullanae. Wszystko to miało stanowić przygotowanie do apoteozy, a na działaniach Sulli wzorował się później Oktawian August.

W podobnym duchu charakteryzował politykę religijną Sulli Jerome Carcopino, autor przełomowej pracy, opublikowanej w 1931 roku pt. Syllaou la monarchie manquée ${ }^{30}$. Uznał on, że działania dyktatora były podporządkowane zapewnieniu deifikacji po śmierci. Służyć miały temu nie tylko wspomniane odwołania do bóstw, ale również nadzwyczajne uprawnienia religijne, jak prawo do poszerzania pomoerium nadane Sulli w 82 roku p.n.e. na mocy lex Valeria. Ważnym elementem władzy stały się auspicia, których symbolem była laska auguralna. Istotną zasługą dyktatora było również odnowienie po pożarze świątyni Jowisza kapitolińskiego.

Hipoteza o świadomym dążeniu Sulli do apoteozy po śmierci jest współcześnie kwestionowana, a wymienione wyżej działania uznaje się raczej za formę „autoprezentacji” podkreślającej jego wyjątkowość jako wodza i polityka ${ }^{31}$.

Kolejnym przełomem w procesie kreowania władzy charyzmatycznej i kultu wodza jest działalność Gajusza Juliusza Cezara. Cezar już od młodych lat zdawał sobie sprawę z roli funkcji kapłańskich w działalności politycznej. W 87 roku p.n.e. został on mianowany kapłanem Jowisza (flamen Dialis), a w 73 roku p.n.e. wszedł do kolegium pontyfików na miejsce swego wuja M. Aureliusza Kotty ${ }^{32}$. Ukoronowaniem „kapłańskiej” kariery Cezara był urząd wielkiego pontyfika (pontifex maximus), który objął

30 J. Carcopino, Sylla ou la monarchie manquée, Paris 1931 (rozdz. VII).

31 H. Behr, Die Selbstdarstellung Sullas. Ein aristokratischer Politiker zwischen persönlichem Führungsanspruch und Standessolidarität, Frankfurt/M., Berlin, Bern, New York, Paris, Wien 1993.

32 L. Ross Taylor, Caesar's Early Career, „Classical Philology” 1941, t. 36, s. $113-132$. 
w 63 roku p.n.e. Cezar przywiązywał bardzo dużą wagę do tej funkcji, ponieważ była mu wielce pomocna w realizacji głównego celu politycznego, czyli osiągnięcia najwyższej władzy w państwie ${ }^{33}$. W 62 roku p.n.e., jak podaje Swetoniusz, fakt sprawowania wielkiego pontyfikatu uchronił Cezara przed działaniami senatu, mającymi na celu pozbawienie go funkcji pretora. Cezar odesłał liktorów, zrzucił urzędniczą togę (toga praetexta) i schronił się w swym mieszkaniu, gdzie jako pontifex maximus był nietykalny ${ }^{34}$.

Szczególnego znaczenia funkcja ta nabrała jednak w okresie II wojny domowej i dyktatury, kiedy Cezar postanowił rozszerzyć swoje kompetencje religijne. W 47 roku p.n.e. został wybrany augurem, uzyskując tym samym dodatkowe uprawnienia do prowadzenia auspicjów, co upamiętniają emisje monet z wizerunkiem zakrzywionej laski (lituus) ${ }^{35}$. Część badaczy widzi w nim nie tylko oznakę auguratu, ale także symbol najwyższego imperium oraz władzy religijnej związane z pełnieniem urzędu kapłana najwyższego ${ }^{36}$. $\mathrm{Na}$ monetach Cezara z tego okresu znalazły się również inne akcesoria niezbędne w sprawowaniu funkcji kapłańskich: szpiczasta czapka (apex), topór (securis), kropidło (aspergillum), czerpak (simpulum), rytualne naczynie (capis) z towarzyszeniem legendy: AVGVR PONT MAX. L. Morawiecki wysunął hipotezę, że kumulację tych symboli można interpretować nie jako przedstawienie poszczególnych funkcji kapłańskich, ale jako zapowiedź wyjątkowej pozycji religijnej Cezara ${ }^{37}$.

W napisach poświęconych Cezarowi, pochodzących z Grecji, zwłaszcza tych datowanych na okres po bitwie pod Farsalos, eksponowane jest połączenie władzy politycznej i religijnej, o czym świadczą takie występu-

${ }^{33}$ G. Huber, Untersuchungen zu Caesars Oberpontifikat, Diss. Tübingen 1971; S. Weinstock, Divus Iulius, Oxford 1971, s. 28 i n.

34 Suetonius, Caesar 16.

${ }^{35}$ M. Crawford, Roman Republican Coins, vol. 1, Cambridge 1974, no 456/1 a-b; 466/1; 467/1; 467 a-b.

${ }^{36}$ L. Morawiecki, Symbole urzędów religijnych na monetach republiki rzymskiej, [w:] Religie w świecie starożytnym, red. D. Musiał, M. Ziółkowski, Toruń 1993, s. 72-79.

${ }^{37}$ M. Crawford, RRC, No. 443/1; 456/1 a-b; 466/1; 467/1 a-b. Por.: A. Alföldi, The Main Aspects of Political Propaganda on Coinage of the Roman Republic, [w:] Essays in Roman Coinage Presented to Harold Mattingly, ed. R. A. G. Carson, C. H. V. Sutherland, Oxford 1956, s. 63-95; L. Morawiecki, op.cit., s. 72-79. 
jące obok siebie terminy, jak imperator i pontifex maximus (archiereus), przy czym ten drugi tytuł zastępowany był też określeniem theos ${ }^{38}$. Także w inskrypcjach italskich poświęconych Cezarowi podkreślany jest związek władzy politycznej i religijnej (imperator-pontifex maximus - parens patriae) ${ }^{39}$. L. Ross Taylor sugerowała, że pontyfikat Cezara był jednym z etapów kwalifikujących go to divine rulership, E. Taeger uważał tę funkcję za kluczową dla kształtowania się władzy charyzmatycznej dyktatora ${ }^{40}$.

Kolejne etapy kształtowania się władzy charyzmatycznej w Rzymie wiążą się z oficjalnym ubóstwieniem Cezara, przeprowadzonym przez Oktawiana Augusta. Wprawdzie S. Weinstock uznał, że Cezar był uważany za boga jeszcze za życia, ale większość badaczy nie podziela tej opinii. Przyjmuje się, że przyznane Cezarowi za życia zaszczyty, jak prawo do paradnego łoża (pulvinar), na którym kładziono zwykle posągi bogów i spiczastego dachu przypominającego zwieńczenia świątyń (fastigium), który zdobił dach domu Cezara, czy prawo do posągu w świątyni (simulacrum), odrębnego kapłana (flamen), złotego krzesła w kurii i w sądzie, wozu (tensa) i noszy (ferculum) używane do transportu posągu podczas ludi circenses itd. nie oznaczały bezpośredniego uznania go za boga ${ }^{41}$.

Po śmierci dyktatora te nadzwyczajne honory przyznane Cezarowi przez senat różnie były odbierane. Appian wspomina, że kiedy Oktawian podjął próbę ustawienia złoconego krzesła podczas ludi Caeriales, organizujący ceremonię edyl sprzeciwił się, w czym uzyskał wsparcie Marka Antoniusza, pełniącego wówczas konsulat ${ }^{42}$. Oktawian był jednak konsekwentny w dążeniu do ubóstwienia swojego przybranego ojca. Decydujące

${ }^{38}$ A. Raubitschek, Epigraphical notes on Julius Caesar, „Journal of Roman Studies” 1954 , t. 44, s. 65-75.

${ }^{39}$ R. Stepper, Der Oberpontifikat von Caesar bis Nerva. Zwischen Tradition und Innovation, [w:] Zwischen Krise und Alltag. Antike Religionen im Mittelmeerraum, red. C. Bartsch, U. Egelhaaf-Gaiser, R. Stepper, Stuttgart 1999, s. 171-185.

${ }^{40}$ L. Ross Taylor, The Divinity of the Roman Emperor, Middleton 1931, s. 59 i n.; F. Taeger, Charisma, t. 2, s. 124 n.

${ }^{41}$ Cicero, Philippicae II, 43, 110-111; Plutarch, Caesar 63; Suetonius, Caesar 76; Appian, Bella Civilia II, 106; S. Weinstock, Divus Iulius, Oxford 1971, 31 i n. Por.: M. Beard, J. North, S. R. F. Price, Religions of Rome, t. 1, Cambridge 1998, s. 140 i n.

${ }^{42}$ Appian, Bella civilia III, 28. 
znaczenie w tym procesie miały wydarzenia, które rozegrały się pod koniec lipca 44 roku p.n.e. podczas ludi Victoriae Caesaris. Zauważono wówczas kometę, którą uznano za duszę Cezara, wziętą do nieba. Swetoniusz pisze: „W czasie uroczystości, które po raz pierwszy wydał na jego cześć po ubóstwieniu spadkobierca August, przez dni siedem bez przerwy świeciła kometa wschodząca koło jedenastej godziny. Uwierzono, że to dusza Cezara przyjętego do nieba" ${ }^{43}$. We wrześniu tego samego roku senat de facto uznał boskość, podejmując szereg uchwał, o czym wspomina Cyceron. Sam Arpinata wprawdzie w obradach nie uczestniczył, ale odniósł się do nich w pierwszej „Filippice”. Z jego słów wynika, że senat uchwalił zorganizowanie ku czci Cezara specjalnych Parentalia i supplicationes ${ }^{44}$. Cyceron nazwał te obrzędy: inexpiabiles religiones i kwestionował zasadność otaczania śmiertelnika kultem należnym bogom.

\section{The Beginnings of Cult of Military Leaders and Charismatic Power in Rome during the Late Republic}

(SUMMARY)

In 1985 "Athenaeum" published the article by Maria Jaczynowska La genesi repubblicana del culto imperiale. Da Scipione l'Africano a Giulio Cesare, in which the author analyzed the origin of the cult of Roman military leaders, linking it with the development of the institution of triumph and imperial ideology as well as Hellenistic influences.

Military victories of Roman military leaders deserved special honors or even certain forms of "worship" to which Hellenistic rulers were entitled as deities. A kind of distinguishing feature of the leaders were also the attributes that made up their charisma. A characteristic of charismatic power, apart from contacts with

43 Suetonius, Caesar 88. Por.: Plutarch, Caesar, 69: Iulius Obsequens; 68: Ludis Veneris Genetricis quos pro collegio fecie stella hora undecima crinita sub septemtrionis sidere exorta convertit omnium oculos. Quod sidus quia ludis Veneris apparuit divo Iulio insigne capitis consecrari placuit.

${ }^{44}$ Cicero, Philippicae I, 5, 12 - 6, 13. 
deities, was having divine virtues associated with their incarnation in man, which also had an independent divine existence: virtutes.

Three stages can be distinguished in the development of the cult of Roman military leaders and creation of their charismatic power during the Late Republic in Rome. The first was the period of the Second Punic War, its representatives being Scipio the African and M. Claudius Marcellus, the second was Sulla's policy, and the conclusion was Caesar's policy culminated with his deification after his death.

Henryk Kowalski

Instytut Historii, Uniwersytet Marii Curie-Skłodowskiej w Lublinie hkowalski2@wp.pl 